\title{
Food Insecurity: Challenges of Agricultural Extension in Developing Countries
}

\author{
M. G. Maiangwa*, RA. Omolehin*, O.B. Adeniji**, and U.S. Mohammed ${ }^{\star \star}$ \\ *Dept. of Agricultural Economics and Rural Sociology, \\ Ahmadu Bello University, Zaria. \\ ${ }^{* *}$ Dept. of Agricultural Economics and Extension, \\ Federal University of Technology, Minna.
}

\begin{abstract}
The emphasis on accelerated agricultural development by developing countries was meant to achieve food security. However, food insecurity has remained a problem throughout much of the developing world and is the result of such factors as slow (as well as highly variable) growth in domestic food production, rapid population growth rates, limited financial capacity to import food and inadequate external assistance. Agricultural extension, on the other hand, plays an important role in development by assuring adequate and timely access by farmers to relevant advice, with appropriate incentives to adopt new technologies if it suits their socioeconomic and agroecological circumstances. This paper discusses: the concepts of food security and food insecurity; the causes and consequences of food insecurity; the short-run and long-run measures for alleviating food insecurity; the strengths and weaknesses of some extension modalities; and the modifications to existing extension systems for the achievement of food security. The conclusions drawn are that: (a) improvements in nutritional standards and food security will involve not just a certain rate of agricultural growth, but reduction in population growth rates; and (b) modifications to extension services have the potential to improve agricultural productivity, increase farmers' incomes, and improve food security.
\end{abstract}

\section{INTRODUCTION}

Developing countries have strongly emphasized acceleration of agricultural development for food security. However, there has been only modest progress in diminishing the threat of food insecurity (annual consumption variation) mainly because of the countries' large year-to-year variations in grain production, financial inability to import food, and inadequate external assistance (Rosen and Shapouri, 1994). Analysis of food security in the 1970s focused largely on the scarcity of food supply, usually caused by drought, disease or war (Ali and Pitkin, 1991). As a result, many developing countries pursued policies of food self-sufficiency that emphasized increasing domestic production and reserve stocks. The assumption inherent in these policies was that food surpluses at the national level are 
translated into food security at the household level (Ali and Pitkin, 1991). Unfortunately, this has not been the case (Ali and Pitkin, 1991).

For developing countries, there are two main food supply problems. One is the growing long-term deficit in domestic food supply, and the other is the short-term instability in food supply (Rosen and Shapouri, 1994). Extension services, on the other hand, provide human capital-enhancing inputs, including information flows that can improve rural welfare - an important outcome long recognized in the development dialogue (Leonard, 1977; Garforth, 1982; Jarrett, 1985; Feder et al., 1986; and Roberts, 1989). That interest continues in contemporary dialogue as evident in the workshop on public extension services convened by the World Bank, the United States Agency for International Development, and the Nenchatel Group to review recent approaches to revitalizing extension services (World Bank, 2002). Studies have indicated that investments in extension services have the potential to improve agricultural productivity and increase farmers' incomes, especially in developing economies, where more than 90 percent of the world's nearly 1 million extension personnel are located (Anderson and Feder, 2004). Yet, the impact of extension on farm performance is varied, reflecting differences in how extension services are delivered and in the circumstances of service recipients.

This paper is divided into 5 sections. Section 1 is the introduction. Section 2 reviews the concepts of food security/food insecurity, the causes of food insecurity and the consequences of food insecurity. Section 3 outlines the measures for achieving food security both in the short-run and the long-run. Section 4 discusses the virtues and limitations of some extension modalities. Section 5 focuses on the modifications to extension for the achievement of food security; and section 6 contains the summary, conclusion and recommendations.

\section{Concepts of Food security and Food insecurity}

Food security can be defined as: (a) "access by all people at all times to enough food for an active healthy life" (USDA, 1992); and (b) "the ability of food-deficit countries to meet target consumption levels on an annual basis (Rosen and Shapouri, 1994). The target consumption could be some nutritional target, average consumption over a period of years or the trend level of consumption, (Rosen and Shapouri, 1994). Food security, by definition, is therefore not simply about availability of food. It also entails (i) accessibility, that is, the ability of individuals or a nation to acquire food on a sustainable basis; and (ii) the reliability and distribution of food. The former relates to utilization and consumption of safe and nutritious food, while the latter relates to the equitable provision of food to points of demand at the right time and place (Mkanawire, 2002).

Food security is not determined by where the food is produced, but by whether individuals have access to it. Sen's (1986) study of major 20th century famines found that acute food insecurity can occur even when ample food is available in a country. Conversely, food insecurity can be defined as the lack of access to enough food (Cernea, 1988a). What is 'enough food' has been reported to be often a matter of cultural interpretation, but which can be nutritionally and medically defined based on the caloric content of food needed to maintain a 
healthy, working life (Cernea, 1988a). There are two kinds of food insecurity: chronic and transitory. Chronic food insecurity is characterized by a continuously inadequate diet, caused by the incapacity to produce, purchase, or otherwise obtain sufficient food (Cernea, 1988a; USDA, 1992). Transitory food insecurity is a temporary decline in a household's access to sufficient food, stemming from fluctuations in production or incomes (USDA, 1992). The distinction between "chronic" and "transitory" can become a semantic one at times, because of the difficulty of determining the point in time at which transitory food insecurity lapses into chronic shortage (Cernea, 1988a).

\section{The causes of food insecurity:}

(a) Rapid population increases: Africa's average population growth rate of 2.8 percent remains the highest in the world (World Bank, 2002). In some countries, the rate is considerably higher (see Table 1). Although fertility rates have begun to decline in a few African countries, overall Africa is the only region where the 6- to 11-year age group is still growing (World Bank, 2002). In addition, unlike other regions where the ratio of dependents to working-age population has fallen to one-half, the age-dependency ratio in Africa has remained close to 1 (World Bank, 2000). Rapid population growth increasingly overwhelms African countries' physical, economic, and social service capacity to provide for the needs of their people. The results are high unemployment; malnutrition; overcrowded and underserviced squatter settlements, classrooms and clinics; and smallholder farms subdivided to the point that they are too small to support a household (World Bank, 2002). Thus, even with agriculture growing at 4 percent per annum, Africa will have great difficulty feeding itself if population growth continues at over 3 percent per annum.

Case 1 in Table 2 shows the staggering food import requirements if present population and agricultural growth trends were to continue. The food gap, even at the present low average per capita food consumption levels (about 202 $\mathrm{kg} / \mathrm{cap} / \mathrm{year}$ ), would increase from 10 million tonnes maize equivalent at present to 24 million tonnes by the year 2000 and to 80 million tonnes, twenty years later (Cleaver, 1993). In case V, Table 2, even sustained growth in food production averaging 4 percent per year and a steady decline in the rate of population growth to 2.3 percent per annum during the decade $2010-2030$, the food gap would remain at roughly its present level of about 10 million tonnes per annum until 2010 and would not be closed until about the year 2015 (Cleaver, 1993).

It is, therefore, clear that even with 4 percent annual growth in food production, the important objective of bringing the percentage of the population subject to food insecurity down to zero over the next three decades cannot be achieved, at the aggregate level, unless population fertility rates are reduced by 50 percent and the population growth rate is thereby lowered to about 2.3 percent per annum by the year 2025 (Cleaver, 1993). The desirable targets for sub-Saharan Africa are that: agricultural production needs to grow at about $4 \%$ per year on average; per capita daily calorie consumption should be increased to 2,500 by the year 2010 (though 2,400 calories are reported as adequate for a normal healthy life); population growth falls to $2.1 \%$ per year by the year 2020 , and the percentage of the 
population who are food insecure drop to $0 \%$ by the year 2020 (Cleaver 1992a). More specifically, in the case of Nigeria, the desirable targets (in percentage) in terms of annual agricultural production growth, annual population growth, daily per capita consumption and population food insecure are 4.0, 2.1, 2,400 and 5, respectively (Cleaver, 1992a).

TABLE 1: Population Growth Rates of Some African countries

\begin{tabular}{|c|c|c|c|c|}
\hline \multirow[t]{2}{*}{ Country } & \multirow{2}{*}{$\begin{array}{c}\text { Total } \\
\text { population } \\
\text { (thousands) } \\
1998\end{array}$} & \multirow{2}{*}{$\begin{array}{c}\text { Total } \\
\text { population } \\
\text { (millions) } \\
2015\end{array}$} & \multicolumn{2}{|c|}{$\begin{array}{c}\text { Average annual } \\
\text { growth rate (percent) }\end{array}$} \\
\hline & & & $1980-98$ & 1998-2015 \\
\hline & $\begin{array}{l}\text { Fastest } \\
\text { growing }\end{array}$ & & & \\
\hline Angola & 12.0 & & 3.0 & 2.8 \\
\hline Benin & 5.9 & & 3.0 & 2.5 \\
\hline Botswana & 1.6 & & 3.0 & 0.9 \\
\hline Congo, Dem. Rep. & 48.2 & & 3.2 & 2.9 \\
\hline Gabon & 1.2 & & 3.0 & 2.2 \\
\hline The Gambia & 1.2 & & 3.6 & 2.2 \\
\hline Ghana & 18.5 & & 3.0 & 2.2 \\
\hline Kenya & 29.3 & & 3.1 & 1.7 \\
\hline Malawi & 10.5 & & 3.0 & 2.2 \\
\hline Niger & 10.1 & & 3.3 & 3.0 \\
\hline Tanzania & 32.1 & & 3.0 & 2.0 \\
\hline Togo & 4.5 & & 3.0 & 2.0 \\
\hline & $\begin{array}{l}\text { Slowest } \\
\text { growing }\end{array}$ & & & \\
\hline Burundi & 6.5 & & 2.6 & 2.0 \\
\hline Guinea & 7.1 & & 2.6 & 2.0 \\
\hline Guinea-Bissau & 1.2 & & 2.1 & 1.8 \\
\hline Lesotho & 2.1 & & 2.4 & 1.6 \\
\hline Mauritius & 1.2 & & 1.0 & 0.9 \\
\hline Mozambique & 16.9 & & 1.9 & 2.0 \\
\hline Rwanda & 8.1 & & 2.5 & 2.2 \\
\hline Sierra Leone & 4.9 & & 2.3 & 1.9 \\
\hline South Africa & 41.4 & & 2.3 & 1.0 \\
\hline Sudan & 28.3 & & 2.3 & 2.1 \\
\hline Sub-Saharan Africa & 627.1 & & 2.8 & 2.2 \\
\hline
\end{tabular}

Source: World Bank, 2000b 
TABLE 2: Sub-Saharan Africa: Population and Food Security, 1990-2020

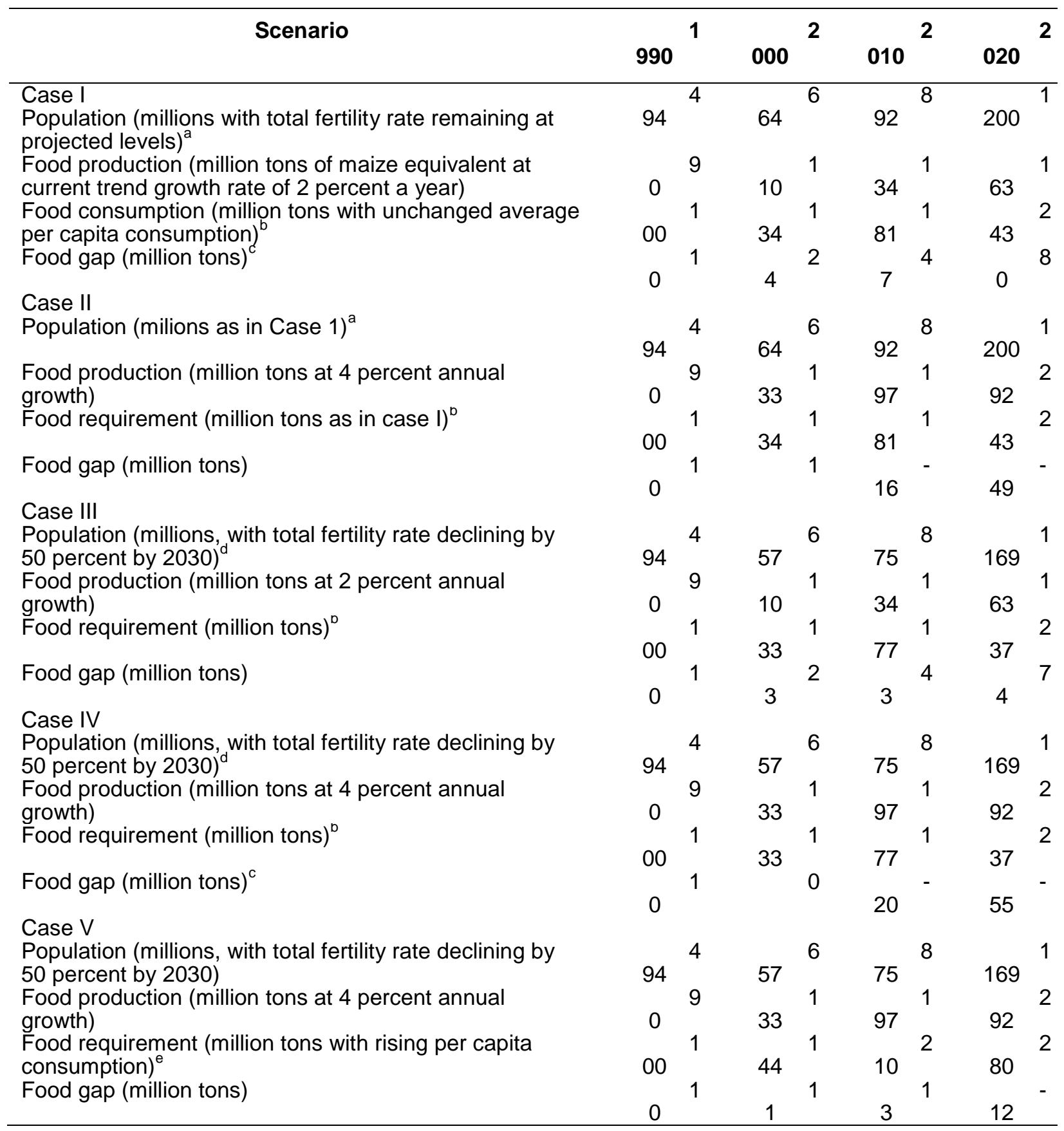

${ }^{a}$ Population growth at 3.0 percent per annum.

${ }^{\mathrm{b}}$ Average of 2027 calories per person per day.

${ }^{c}$ Equals consumption requirement minus production; negative sign denotes production surplus. This equaled the cereal imports plus food aid in 1990 .

d Target.

e Average per capita consumption rising to 2,200 calories per day by 2,000 to 2,400 calories per day by 2010 and stabilizing at that level thereafter. 
(b) Slow and variable growth in domestic food production: In most countries, domestic production remains the primary component of consumption, (Rosen and Shapouri, 1994; Borlaug and Dowswell, 2004). As a result, variations or shortfalls in production are directly transmitted to consumption. There are two important production characteristics which contribute to a country's ability or inability to meet its domestic food requirements: growth and variability (USDA, 1992). Production growth in low-income countries has generally been constrained by limited natural resources, inadequate incentives, poor infrastructure, lack of inputs, and unfavourable weather (USDA, 1992). In addition to the domestic production growth rate, a country's production variations must be examined to make an accurate assessment of its food aid needs (USDA, 1992).

Countries where low production growth is coupled with high variation are extremely vulnerable to shortfalls (USDA, 1992). For example, in Nigeria, the degree of instability in the growth performance of the agricultural sector between 1981 and 2000 is shown in Table 3. The variability which is measured in terms of coefficient of variation shows the average percentage variation in either direction from the mean value from one year to the next. A coefficient of variation of zero percent depicts perfect stability and the higher it is from zero, the higher is the degree of instability, subject to a maximum of $100 \%$. Instability in an agricultural performance indicator is a reflection of policy instability and/or implementation inconsistency, vagaries of nature (which is a prominent phenomenon affecting most agricultural activities), policy failures, market failures (e.g. unreliable input supply system, unstable input and output prices, etc.), and other weaknesses of the economy (Manyong et al., 2005). Looking at Table 3, it could be observed that most of the indicators had high average coefficients of variation (say, $>20 \%$ ) over the subperiods under review.

It may therefore be concluded that high instability was a hallmark of the agricultural sector with most important indicators in the sector displaying wild periodic fluctuations from good performance to bad performance and vice versa. Thus, a very unstable growth pattern characterizes Nigeria's agriculture. As indicators of the food security situation in Nigeria in recent years, the average daily intake of calorie and protein from major food sources is presented in Table 4. As shown, average daily calorie intake from cereals and tubers (which provide about $90 \%$ of calories from all food sources) increased marginally by about $1 \%$ in the whole of the $1996-2000$ subperiod. Average daily protein intake from animal and fish sources, however, increased more substantially by about $16 \%$ in the whole of the $1996-2000$ subperiod. Overall therefore, it would appear that the average food security situation, measured in terms of calorie and protein intake, increased in the $1996-2000$ subperiod, but only very marginally. Thus, overall, it would appear that the average Nigerian was still marginally below the minimum daily 
calorie intake of $2250-2400$ kilo calories and minimum protein intake from animal sources of 35 grammes per day (Cleaver, 1993; Olayemi, 1995).

Households generally get food through a combination of their own production and purchases (Ali and Pitkin, 1991). In many rural areas, households do not grow enough food to meet their needs. In Tanzania, it was found that in 80 percent of

the households surveyed in 21 villages, the main food grains lasted for only six to eight months after harvest (Ali and Pitkin, 1991). In the southern region of Malawi, about 87 percent of households were found to deplete their food stocks three to four months before harvest (Ali and Pitkin, 1991). Also, a large number of rural households sell their main food crop in order to get cash to purchase other essentials. They do so even though they know that what remains will not meet their own annual food needs and that prices are often lowest at harvest time (Ali and Pitkin, 1991). 
TABLE 3: Variability in agricultural sector performance indicators (coefficients of variation in percentage)

\begin{tabular}{|c|c|c|c|c|}
\hline Indicators & 1981-1985 & $1986-1990$ & 1991-1995 & $1996-2000$ \\
\hline $\begin{array}{l}\text { GDP at } 1984 \\
\text { constant factor } \\
\text { cost } \\
\text { Crops } \\
\text { Livestock } \\
\text { Forestry } \\
\text { Fisheries } \\
\text { Total agriculture } \\
\text { GDP } \\
\text { Total GDP } \\
\text { Index of } \\
\text { agricultural } \\
\text { production } \\
\text { Staple crops } \\
\text { Other crops } \\
\text { Livestock } \\
\text { Fisheries } \\
\text { Forestry } \\
\text { Sector aggregate } \\
\text { Guaranteed loan } \\
\text { under ACGSF } \\
\text { Total bank credit } \\
\text { Credit to } \\
\text { agriculture } \\
\text { Credit to the } \\
\text { economy } \\
\text { Consumer price } \\
\text { index } \\
\text { All items } \\
\text { Food items } \\
\text { Capital } \\
\text { expenditure of } \\
\text { Federal } \\
\text { Government } \\
\text { Expenditure on } \\
\text { agriculture } \\
\text { Expenditure on all } \\
\text { sectors }\end{array}$ & $\begin{array}{c}7.5 \\
5.4 \\
6.6 \\
29.9 \\
3.2 \\
4.3\end{array}$ & $\begin{array}{c}22.3 \\
10.4 \\
18.1 \\
12.6 \\
4.2 \\
18.1 \\
22.4\end{array}$ & $\begin{array}{c}25.4 \\
3.2 \\
1.6 \\
6.5 \\
1.4 \\
8.2 \\
33.4\end{array}$ & $\begin{array}{c}6.2 \\
3.5 \\
2.9 \\
14.2 \\
6.1 \\
3.6 \\
\\
4.7 \\
8.1 \\
3.5 \\
8.9 \\
2.1 \\
5.3 \\
42.2\end{array}$ \\
\hline
\end{tabular}

Source: Manyong et al., 2005 
TABLE 4: Performance indicators in recent years (1996-2000)

\begin{tabular}{|c|c|c|c|c|c|c|}
\hline Indicators & 1996 & 1997 & 1998 & 1999 & 2000 & 2001 \\
\hline $\begin{array}{l}\text { Share of agriculture in real } \\
\text { GDP }(\%)\end{array}$ & 39.0 & 39.4 & 40.1 & 41.0 & 40.6 & 41.1 \\
\hline $\begin{array}{l}\text { Annual growth rate of } \\
\text { agriculture's real GDP (\%) }\end{array}$ & 4.1 & 4.2 & 4.0 & 5.2 & 2.9 & 5.1 \\
\hline $\begin{array}{l}\text { Agriculture's share of total } \\
\text { value of export (\%) }\end{array}$ & 1.3 & 1.6 & 2.2 & 1.0 & 2.2 & - \\
\hline $\begin{array}{l}\text { Average per caput calorie } \\
\text { intake from cereals and tubers } \\
\text { (Kcal/day) }\end{array}$ & 2145.7 & $\begin{array}{l}2147 . \\
1\end{array}$ & $\begin{array}{l}2157 . \\
6\end{array}$ & $\begin{array}{l}2161 . \\
3\end{array}$ & $\begin{array}{l}2165 . \\
0\end{array}$ & - \\
\hline $\begin{array}{l}\text { Average per caput protein } \\
\text { intake from animal and fish } \\
\text { sources (g/day) }\end{array}$ & 14.2 & 15.7 & 16.1 & 16.2 & 16.5 & - \\
\hline
\end{tabular}

Source: Manyong et al., 2005

(c) Limited financial capacity to import food: Most developing countries export agricultural and other primary products (metals, fuel, and minerals) and rely on one or a few commodities for more than half of their export earnings (USDA, 1992). In most cases, shipments from these countries are not large enough to influence the world market (USDA, 1992). Consequently, export revenues are vulnerable to world demand fluctuations as well as the variability in domestic production (USDA, 1992). Thus, if a country's financial resources are constrained, the possibility of importing commercially is limited. Imports that cushion the variability of production have been divided into commercial and food aid. The ability to import commercially is primarily driven by the availability of foreign exchange, which in many developing countries has been limited by slow growth in export earnings and large debt service obligations (Rosen and Shapouri, 1994). The addition of food aid to production and commercial imports also tends to reduce consumption variability. One major reason for the limited impact of food aid in reducing consumption variation, however, is timing, especially for emergency assistance Delays at different stages of the process - assessment, response to needs, and distribution - are common (Rosen and Shapouri, 1994).

(d) Lack of efficient food markets: The key constraint to market access and the emergence of efficient markets is the high degree of official regulation and administration (Ali and Pitkin, 1991). In some cases, food crops produced by smallholders may only be marketed through parastatal marketing boards (Ali and Pitkin, 1991). Farmers are often prohibited from selling directly to consumers, processors, or private traders. Prices for most major commodities, as well as agricultural inputs, are determined administratively rather than through the market. For example, in Nigeria, domestic prices for the principal cash crops - oil palm, 
cocoa, rubber, cotton, and groundnuts - used to be set by the respective Commodity Boards, which were dismantled in 1986. These prices tend to be low, thereby depressing incentives to produce a market surplus. Also, private traders, transporters, and processors are controlled by a host of regulations and licensing systems (Ali and Pitkin, 1991). The presumption is that major policy concerns national food security, exports of key commodities, income stabilization, and promotion of new crops - are best served by an expanding publicly-controlled marketing system (Ali and Pitkin, 1991). The reality is that officially-controlled pricing and marketing systems are often cumbersome and inefficient and aimed at serving urban areas.

(e) Low household incomes: Low incomes compound the problem of inefficient markets for food. In a survey in the Mutoko Communal Area in Zimbabwe, it was found that food-insecure households tend to be poor households that lack the resources to raise the productivity of their land and labour (Ali and Pitkin, 1991). A number of factors constrain increased productivity and earning power. Agricultural policies emphasizing increased production of staple food crops and inefficient marketing systems have prompted farmers to place a high priority on subsistence production (Ali and Pitkin, 1991). The net result is a largely undiversified agricultural sector which can result in high variability in production incomes (Ali and Pitkin, 1991). Small land holdings can also constrain incomes. In Africa, the average amount of land per capita is among the lowest in the world, ranging from about 0.1 to 0.6 hectare per capita (World Bank, 2002). Recent data shows that 55 percent of all households in Malawi have access to less than one hectare of land. A simple calculation reveals the inadequacy of this holding size: an average household of five persons with annual per capita caloric requirements of 216 kilogrammes of maize, and average yields of 800 to 1000 kilogrammes per hectare needs between 1 and 1.3 hectares of land just to meet household subsistence food requirements.

(f) Limited use of agricultural inputs: Low yields are due to the low intensity of agriculture, particularly the limited use of fertilizer and improved seeds (Ali and Pitkin, 1991). For example, although increased consumption of chemical fertilizer is essential in most smallholder agricultural systems, at present only around 9 kilogrammes of nutrients per hectare are used for agriculture in sub-Saharan Africa and only half this amount is used for growing food crops - compared with 10 to 20 times as much as in the industrialized nations (Table 5). Similarly, while farmers are expected to endeavour to use all of the organic nutrients that are economically feasible not only to replenish nutrients but to improve overall soil structure and health as well, there simply are not enough organic manures and crop residues available to replenish and maintain soil fertility in the higher-yielding production systems needed to meet growing food requirements and reduce poverty (Borlaug and Dowswell, 2004).

In Malawi, the use of hybrid maize has never exceeded 10 percent, and less than a quarter of smallholders apply fertilizer to any crop (Ali and Pitkin, 1991). The demand for inputs is hindered by lack of credit, and in the case of fertilizer, its low profitability in drier areas. Input supply is hindered largely by a weak distribution 
network. Inputs markets, like output markets, have been largely controlled by the public sector, and while prices of inputs are often subsidized, the benefits generally accrue to more resource-endowed farmers. Low-income smallholders also typically exhibit a limited ability to bear the risk inherent in technical change.

TABLE 5: Fertilizer nutrient consumption per hectare of arable land, 2000

\begin{tabular}{lc}
\hline Country & Amt $\mathbf{( K g} / \mathbf{h a})$ \\
\hline Uganda & 1 \\
Ghana & 3 \\
Guinea & 4 \\
Mozambique & 4 \\
Tanzania & 6 \\
Nigeria & 7 \\
Burkina Faso & 9 \\
Mali & 11 \\
Ethiopia & 16 \\
Malawi & 16 \\
Benin & 18 \\
Cuba & 37 \\
South Africa & 51 \\
India & 103 \\
United States & 105 \\
Brazil & 140 \\
France & 225 \\
China & 279 \\
United Kingdom & 288 \\
Japan & 325 \\
Vietnam & 365 \\
Netherlands & 578 \\
\hline
\end{tabular}

Source: Borlaug and Dowswell, 2004

(g) Pervasive soil fertility problem: Although there are some very fertile areas, much of Africa's soil is of relatively poor quality because of the continent's geological history and climate (World Bank, 2002). Some soils are deficient in key nutrients (e.g. phosphorus), have poor water retention, and are easily eroded and degraded. A global assessment of soil degradation as well as a World Bank strategy for development indicated that across Africa, $65 \%$ of arable cropland and more than $30 \%$ of all permanent pasture are significantly degraded (Oldeman, 1990; World Bank, 1996). The magnitude of nutrient mining in Africa is also enormous. Sanchez et al. (1996) estimates that during the past 30 years, the net per-hectare loss on about 100 million hectares of cultivated land is about $700 \mathrm{~kg}$ of nitrogen, $100 \mathrm{~kg}$ of phosphorus, and $450 \mathrm{~kg}$ of potassium. In contrast, over the same period, commercial farmers in North America and Europe have averaged per-hectare nutrient gains of more than $3,250 \mathrm{~kg}$ of NPK on 400 million hectares. 
(h) Inadequate rural infrastructure: The most basic elements of rural infrastructure comprise rural roads, markets in rural towns, rural water supply facilities, and rural health and education facilities. At a somewhat higher level of development, it includes rural electrification, telecommunication facilities, and access to electronic mass media. These rural infrastructures are highly deficient in most developing countries. Africa, for example, has the fewest kilometres of paved roads per capita in the world (Table 6). Nigeria only has $230 \mathrm{~km}$ per million people, compared with $1064 \mathrm{~km}$ in Brazil, 12,673 km in France and 20,987 km in the United States. Rural road density has also been estimated at about $32 \mathrm{~m} / \mathrm{km}^{2}$ in Western Africa and $36 \mathrm{~m} / \mathrm{km}^{2}$ in eastern and southern Africa (Cleaver, 1993). In Nigeria, with its fairly dense network of rural roads (by African standards), rural road density today is about $90 \mathrm{~m} / \mathrm{km}^{2}$, barely equal to that of India in 1951 .

A reasonable target density, based on Indian areas with comparable population densities would be $730 \mathrm{~m} / \mathrm{km}^{2}$ (Cleaver, 1993). Intensive agricultural production is especially dependent upon access to vehicles at affordable prices. Unfortunately, most agricultural production in Africa is generated along a vast network of footpaths, tracks, and community roads, where the most common mode of transport is the legs, heads, and backs of women. Indeed, the largest part of a household's time expenditure is for domestic transport. This situation places farmers in a double cost/price squeeze - between high farm-gate costs for inputs and low farm-gate prices for output (Borlaug and Dowswell, 2004).

On-farm storage capacity in rural areas tends to be limited with high losses resulting from insects, rodents, rain, and spoilage over time. In Nigeria, less than $20 \%$ of the rural population have convenient access to safe water (Cleaver, 1993). There is a direct link between safe potable water and the reduction of infant mortality. Water-borne and water-related pathogens are major causes of seasonally or permanently debilitating diseases which severely affect agricultural labour productivity. Expanding numbers of uneducated and unhealthy rural people are also unlikely to be able to develop agriculture at the necessary speed. 
TABLE 6: Length of paved roads per million people in selected countries

\begin{tabular}{lc}
\hline Country & Roads $\mathbf{( k m )}$ \\
\hline United States & 20,987 \\
France & 12,673 \\
Japan & 9,012 \\
Zimbabwe & 1.586 \\
South Africa & 1,402 \\
Brazil & 1,064 \\
India & 1,004 \\
China & 803 \\
Guinea & 637 \\
Ghana & 494 \\
Nigeria & 230 \\
Mozambique & 141 \\
Tanzania & 114 \\
Uganda & 94 \\
Ethiopia & 66 \\
\hline
\end{tabular}

Source: Borlaug and Dowswell, 2004

\section{Consequences of food insecurity}

The costs and consequences of inadequate diets and hunger in terms of untold human sufferings are enormous and impossible to quantify. For example, chronic and transitory food insecurity increase morbidity rates, cause stunted growth in children and chronic illnesses, sap the strength needed for work and other tasks, and reduce the benefits of schooling and the productivity of the people affected (Cernea, 1988a). In a vicious circle, the poverty that causes undernourishment in the first place is reinforced and perpetuated (Cernea, 1988a). Deprivation turns into starvation and decreases life expectancy (Cernea, 1988a).

The vulnerability to food insecurity is unevenly distributed. Rural people constitute the vast majority of the world's poor and ultra-poor, but food insecurity affects tragically large numbers of urban poor as well (Cernea, 1988a). The social groups at highest risk are those below the poverty thresholds: small-scale farmers or tenants; landless labourers and the near landless; sharecroppers; urban unemployed or underemployed, ethnic or indigenous minorities, etc. (Cernea, 1988a). Other groups too may see their food security sharply jeopardized: for instance, groups involuntarily displaced from their land and habitat by large reservoirs or urban infrastructure; special gender or age groups such as pregnant and lactating women; the elderly; and other marginal groups whose net incomes abruptly fall (Cernea, 1988a; Cernea, 1988b). 


\section{Alleviating short-run and long-run food insecurity problems Short-run food security issues}

To deal with short-run food affordability problems, governments generally have available three broad approaches: providing social safety nets, intervening to reduce food prices, and ensuring supply by maintaining stockpiles (Ivanic and Martin, 2008). Social-safety-net approaches, such as the provision of emergency food aid or transfers to the poor, can, in principle, be targeted to those in need. As a result, safety nets have fewer side effects than policies that result in lower food prices for all and can help whether or not the problem arises from changes in food prices (Ivanic and Martin, 2008). By contrast, policies that seek to lower food prices are often ineffective in dealing with many food security problems, such as those resulting from drought-induced declines in farm output, for example (Ivanic and Martin, 2008). Food aid in particular can substitute for or augment market flows of domestically produced food and commercial imports in the face of foreign exchange scarcities and disrupted domestic markets, thereby preventing price rises that would otherwise imperil the food security of poor households that depend on markets for food (Ali and Pitkin, 1991). The weaknesses of food aid, however, are well known. Sustained food aid can make countries dependent on handouts and can also destabilize prices and reduce incentives for local production (Ali and Pitkin, 1991).

To reduce consumption variability, countries have also had to increase food imports. As pointed out earlier, the ability to import commercially is primarily driven by the availability of foreign exchange, which in many developing countries has been limited by slow growth in export earnings and large debt service obligations (Rosen and Shapouri, 1994). In many instances, however, larger food imports come at the cost of reducing imports of essential capital goods and therefore may adversely affect long-term economic growth (Rosen and Shapouri, 1994).

Policy actions to lower domestic food prices - such as the imposition of export taxes or reductions in import tariffs - are administratively easy to implement (Ivanic and Martin, 2008). When world prices of staple foods rose dramatically in late 2007 and early 2008, about 45 percent of developing countries reduced tariffs and/or consumption taxes or other restrictions on food exports (Wodon and Zaman, 2008). But these approaches can have unintended consequences. For example, an export restriction that lowers the domestic price of rice also will result in lower production and increased demand at a time of shortage, will hurt poor farmers who sell rice, and will provide benefits to consumers far above the poverty line (Ivanic and Martin, 2008).

Policies that seek to insulate domestic food markets from changes in world market prices also tend to fuel the fire of the price increases they seek to quell. The imposition of export restrictions by key exporters in late 2007 and early 2008 contributed to the sharp increases in world prices during this period (Ivanic and Martin, 2008). Removal or relaxation of these restrictions can help reduce the pressure on world prices. 
Public stockpiles can be used to cope with short-run food-security challenges, but they are costly and involve difficult management issues (Ivanic and Martin, 2008). There is pervasive uncertainty about the quantity of stocks required and the amount to release at any stage. Moreover, stock management policies can be destabilizing, if, as seems to have happened in 2008, governments attempt to create or expand stocks when food prices are high (Ivanic and Martin, 2008). Most important, food stocks in the granary are not by themselves enough to ensure food security (Ivanic and Martin, 2008). Whether or not public stocks are used, the key to food security is ensuring that poor people have access to food (Ivanic and Martin, 2008).

To combat the effects of temporary food shortfalls, food storage facilities will be necessary at the farm, village, town, and city levels. These hold the buffer stocks of food needed between the onset of food shortfalls and the arrival of aid, imports, or food from elsewhere. Generally, farmers, traders, grain millers, and processing companies will invest in sufficient storage if price policy makes such investment profitable and if financing to construct storage facilities is available (Cleaver, 1993).

Other immediate interventions needed for offering direct assistance to vulnerable groups experiencing transitory shortfalls in available food include consumer subsidies, coupon systems, food rations, food- and fertilizer-for-work programmes, and special nutrition programmes (Ali and Pitkin, 1991). In Nigeria, nutrition improvement programmes to increase the food intake of the poor, early warning systems that facilitate the preparation of contingency plans and the targeted transfer and sale of food to the poor from government stockpiles would be important parts of national food security strategies. For example, it was found that in Nigeria, children under $80 \%$ expected weight-for-age had $33 \%$ increased duration of diarrhoea (Tomkins, 1981). In Africa as a whole, it has been found that: (i) one hundred million people are at risk of developing Iron Deficiency Disorders (IDD) which cause mental retardation, stillbirths, and neurological disorders; (ii) over half of pre-school children and nearly two-thirds of pregnant women have anaemia (largely due to iron deficiency) which reduces work productivity, impairs immune function, reduces school performance and increases the risk of low birth weight and maternal haemorrhage at birth; and (iii) iron supplements and iron fortification are available and highly cost-effective solutions, yet such programmes are unavailable to a large portion of the population (Abosede and McGuire, 1991). On their part, early warning units will be useful in collecting and monitoring crop production data and alerting government of possible food shortages. In Malawi, a major feeding programme conducted through hospitals and clinics annually targets about 80,000 pre-school children and 35,000 expectant and nursing mothers (Ali and Pitkin, 1991). Also, one community-based nutrition project in Malawi includes provision of food supplements, income-generating activities, labour-saving technologies for women to reduce caloric expenditure, and packages of agricultural inputs and food for the lowest-income women (Ali and Pitkin, 1991). Zimbabwe's Child Supplementary Feeding Programme provides a daily supplementary meal to malnourished children less than five years of age in 
nutritionally-vulnerable areas. Communities are responsible for the programmes management and implementation at the village level.

\section{Food security in the long run}

(a) Sustained increases in the real incomes of the poor: The best way to reduce household food insecurity over the long-term is to raise the real incomes of households through sustained economic growth and to ensure that markets are effective in making food available for household purchase as needed (Ali and Pitkin, 1991; Ivanic and Martin, 2008). Development policies that raise the productivity of poor people's assets are essential to achieving such sustained income increases (Ivanic and martin, 2008). Poor rural households generally have only land and unskilled labour as their principal assets, and thus few human or capital endowments (Barbier, 1999). A recent survey in Africa found that foodinsecure households tend to be poor households that lack the resources to raise the productivity of their land and labour (Ali and Pitkin, 1991). It has been argued that since agricultural households constitute an important market for consumer goods (e.g. textiles, shoes, umbrellas, hurricane lamps, and building materials for homes), investment goods (e.g. seeds, fertilizers, and agricultural implements), and services (transport) produced in the nonagricultural sector, increased incomes of a large number of rural households not only creates employment and incomes in the nonagricultural sector, but reduces poverty and arrests urban migration and population growth, while simultaneously increasing the quality of the population (Lele, 1991).

(b) Expanded trade in food and cash crops: Increased trade can result in expanded farm incomes and employment opportunities for the rural poor (Ali and Pitkin, 1991). Diversification could also result in expanded farm incomes and employment opportunities for the rural poor, enhancing their ability to purchase food - assuming local food markets are available (Ali and Pitkin, 1991). Cash crop earnings could enable smallholder farmers to improve their productivity in food grain production via purchase of fertilizers, or to invest in improved grain storage facilities. At the national level, the potential expansion and increased stability in foreign exchange earnings from trade diversification increases the capacity to import food and agricultural inputs. Broad-based trade liberalization can help raise productivity and income by ensuring that investment goes into the right activities and by promoting technological change (Ivanic and Martin, 2008).

(c) Reorganizing and strengthening national research, extension, and credit services: The aim is to develop more acceptable technological packages and provide the support necessary to ensure widespread adoption of improved technologies among smallholders (Ali and Pitkin, 1991). In Nigeria, the reorganization and strengthening of research should involve, among others, actions as follows: (i) transfer of agricultural research institutes from the direct administrative control of the federal ministries of agriculture to the newly created Agricultural Research Council which is managed mostly by the scientists themselves. The basic concept in creating this new body for the management of agricultural research has been to combine commitment to development with a great deal of autonomy in the management and organization of research (Jain, 
1988); (ii) finance agricultural research, including biotechnology, and the breeding of predators for the biological control of crop pests which the private sector may not be willing to invest in due to the high capital outlay and the relatively low return from agricultural investments; (iii) strengthen and enlarge the capacity of the National Veterinary Research Institute, Vom to produce vaccines; (iv) government manufacturing and promoting the production of agrochemicals by the private sector and ensuring the protection of users, the ecosystem and the environment through appropriate pesticide legislation, and (v) the creation of an Agricultural Development Fund to provide the necessary impetus for the sustainable development of the agricultural sector by supporting both public and private sectors to carry out activities that will boost agricultural and rural development with an emphasis on all facets of agricultural research, market development, extension delivery, long-term credit, rural institution development, and enterprise promotion (Manyong et al., 2005).

With regards to extension, all the three tiers of government should be involved in jointly financing agricultural extension delivery and monitoring its impact. Also, extension service delivery should be streamlined through integration of ADP and State extension services for greater effectiveness. As for credit delivery, the strategies to be adopted should include: (i) provision and improvement of rural infrastructure to attract investment and financial services; (ii) integration and linkage of informal rural financial institutions with the formal banking sector; (iii) expanding the mandate of the re-structured Nigerian Agricultural, Cooperative and Rural Development Bank to include savings mobilization; (iv) modification of the credit delivery system to include the cooperative and community-based organizations as delivery channels to reduce transaction costs; and (v) modification of terms of credit such as interest rate, eligibility criteria, and legal requirement to enhance access (Manyong et al., 2005). In Zimbabwe, a major reorganization of research and extension toward communal farmers has resulted in a relatively high degree of smallholder adoption of technologies for maize and cotton (Ali and Pitkin, 1991). In Malawi, the Mudzi Fund, a specialized credit institution for the rural poor, is showing early signs of success in providing seasonal and medium-term credit to smallholders, most of whom are female farmers, for the purchase of agricultural inputs (Ali and Pitkin, 1991).

(d) Decentralized processing: This can also improve food availability in the rural areas and lower consumer food prices, as well as stimulate other non-farm business opportunities that can raise rural incomes (Ali and Pitkin, 1991). In Nigeria, the suggested thrust of programmes and activities include: (i) promoting and developing agroprocessing for the evolution of virile agro-allied industries and rural microenterprises; and (ii) the promotion of the use of simple but effective onfarm and off-farm agroprocessing technologies to add value to products and increase their shelf life (Manyong et al., 2005). Zambia is also planning to help the private sector establish village-level agro-processing of grains and oilseeds (Ali and Pitkin, 1991). Rural market centres will also be constructed and a training programme for private traders interested in marketing crops established. A line of credit, to be used as working capital or investment resources, will be available to 
private traders to stimulate participation in marketing, processing, and rural transport.

(e) Improved soil resource management: This has the potential of promoting productive and sustainable agricultural systems compatible with the intensification of land use that inevitably accompanies rapid population growth (Jayne et al., 1989). It will, however, require the widespread diffusion of soil- and watermanagement techniques that conserve the resource base, increase and stabilize agricultural production, and are fittable to farmers' resources and goals. These techniques must also be used in an integrated manner, since: (i) they complement each other; and (ii) the clear superiority of any one technique over traditional practices is not always assured unless a combination of two or more new techniques is adopted. The various strategies that have been pursued include split applications and incorporations of fertilizers to maximize use efficiency, timely weeding; introducing green manures, grain legumes, and nitrogen-fixing shrubs and trees into rotations with cereals and roots and tubers; and building up organic matter in the soil profile through mulches. According to Borlaug and Dowswell (2004), these sorts of integrated approaches can increase soil organic matter and improve soil fertility, while reducing the outlays needed for purchased fertilizers.

(f) Investment in rural infrastructure: The importance of rural infrastructure for agricultural development and achievement of food security is well established. Research in Africa has shown that adequate transport links to produce markets stimulate agricultural intensification - even where population densities are comparatively low (Pingali et al., 1987). Farmers with access to roads use land more intensively, more readily adopt efficient techniques and modern inputs, produce more for the market, and employ more labour. This is because farmers with access to roads have access to output and input markets (Cleaver, 1993). Research in Asia also found that in villages with better access to roads, fertilizer costs were $14 \%$ lower, wages were $12 \%$ higher and crop output was $32 \%$ higher (IFPRI, 1990). Convenient sources of safe water are of enormous importance to improve human health and, hence, agricultural labour productivity, and to contribute substantially to a reduction in infant mortality.

A major benefit to women and girls resulting from better access to safe water is that time formerly spent fetching water from distant sources and preparing such water for human use can be used instead for other productive activities, attending school or technical training, tending to children's health and education needs or simply rest and recuperation. Rural water supply investments must be planned and implemented with local community involvement. According to Cleaver (1993), the best results are obtained by a combination of government or local community contracting with private suppliers who undertake to equip local villages, communities or farms. These contractors will often be artisans. Governments can obtain prototype pumps or other equipment from donors.

Maintenance is best done by owners (which are often local communities), sometimes contracting with private suppliers. A more slowly expanding, better educated and healthy rural population would also be better able to develop agriculture. Analysis at the World Bank suggests that one of the most important 
explanatory variables for variations in crop yields over time and between countries is the level of education of the rural population (the other important variables are climate and the policy environment). (Cleaver, 1993). Educated farmers are more productive than uneducated farmers, with other factors affecting agriculture held constant. Similarly, healthy agricultural workers will be more productive than unhealthy workers. In Africa, rural health and education must be concerned with reducing the rate of growth of population. According to Cleaver (1993), a good target would be for population growth rates to fall to about 2.3 percent per annum within the next thirty years. This can be done by: (i) focusing more on creating a demand by individual Africans for smaller families which, in turn, will require better education programmes, targeted more to young women; and (ii) better health care services which increase the likelihood of child survival and reduce the demand for large families. The reason is that one cause of high demand for children by Africans is to assure the survival of at least some children, given the generally high infant mortality rate (Cleaver, 1993).

(g) Creation of off-farm employment opportunities: In countries where a large proportion of the people are dependent on agriculture, getting agriculture to grow faster is the first important step in increasing rural incomes and expanding off-farm employment (Borlaug and Dowswell, 2004). As pointed out earlier, increased incomes of a large number of agricultural households generates productive employment in the nonagricultural sectors through a strong stimulus to nonagricultural growth. The argument is that people unable to produce enough of their own food can obtain food security by generating income outside agriculture with which to buy food (Cleaver, 1993). Farmers concerned with food security have also been shown to devote a significant portion of their resources to nonfood activities as a diversification strategy to spread risks of food crop failures, and to increase incomes (Lele, 1991).

\section{Extension Modalities: Their Virtues and Limitations}

The goals of agricultural extension include transferring information from the global knowledge base and from local research to farmers, enabling them to clarify their own goals and possibilities, educating them on how to make better decisions, and stimulating desirable agricultural development (van den Ban and Hawkins, 1996). The mechanisms of this transfer and the organization of extension vary from country to country. In some industrial countries, there are public and private agricultural extension systems which complement one another. In the United States, for example, the public sector supports county agricultural extension agents who provide advice on agricultural technology to farmers, while private suppliers of fertilizers, pesticides, and equipment offer highly specialized information on the use of their products (Cleaver, 1992b). Farmers can also obtain advice from cooperative organizations as well as universities and research stations.

In sub-Saharan Africa, agricultural extension has been largely confined to the public domain and provided through Ministries of Agriculture, or through parastatals supervised by them. In general, this type of extension service is highly centralized, with a national director in the capital city, supervisors at the regional 
level, and field staff at the local level. The common criticisms of public sector extension systems in Africa are: (a) the extension staff are poorly trained and know little more than the farmers do; (b) the extension staff are poorly paid and therefore have little motivation to share the knowledge they do possess; (c) management systems are poor so that there is little pressure on staff or their managers to seek new knowledge or to serve farmers; (d) farmers are treated as ignorant recipients of information, rather than knowledgeable partners in technology transfer; (e) extension agents are not accountable to farmers; and (f) in some cases, operating facilities, vehicles and bicycles are so scarce that the few motivated and competent extension staff cannot systematically visit farmers regularly (Cleaver, 1993). The result of these defects is typically a large, inert bureaucracy, which has no impact on agriculture.

In the 1960s and 1970s, extension in Africa was financed by donors largely through rural development and commodity development projects. These projects had high failure rates (Cleaver, 1993). World Bank project performance and audit reports found that World Bank agricultural extension systems were poorly managed, and technology was often not relevant to farmers (Cleaver, 1993). Analysis by the World Bank of other donors' agricultural projects led to much the same conclusions (Cleaver, 1993). Technical messages communicated to farmers were often of an extremely general type, purportedly applicable over diverse agroecological conditions, but in fact applicable to only a few, if any. A common problem was poor training of extension agents. This shortcoming was made worse by competition between the various donor-inspired extension systems, often with each delivering contradictory messages (Cleaver, 1993). For example, cotton companies would focus on cotton messages, rural development projects on food crops, and livestock projects on livestock, often in the same places. For the most part, farmers wisely ignored the resulting "noise".

In recent years, disenchantment with traditional extension programmes has grown. High costs and perceived limited impact of the traditional programmes has led to the emergence of new approaches in the design of public agricultural service programmes (World Bank, 2002). These newer approaches, which depart from the traditional public service model, reflect attempts to overcome some of the weaknesses inherent in the public extension systems of recent decades (Anderson et al., 1999; Anderson, 1999; FAO and World Bank, 2000).

(a) Training and Visit Extension: This model of extension organization was promoted by the World Bank during 1975-95 in more than 70 countries (Umali and Schwartz, 1994). The system stressed a single line of command, with several levels of field and supervisory staff; in-house subject matter specialists to provide training to staff and tackle technical issues reported by field staff; exclusive dedication to technical information dissemination; a strict and pre-determined schedule of village visits over a two-week cycle, with contact with selected "contact farmers"; mandatory biweekly training emphasizing the key set of messages for the forthcoming two-week cycle; a seasonal workshop with research personnel; and better renumeration and transport for extension staff (Anderson and Feder, 2004). Although the training and visit design attempted to tackle some of the 
weaknesses of the public extension service, it also exacerbated other weaknesses. In the end, most of these new structures collapsed.

The problems of scale and complexity were tackled by a heavy reliance on formally selected contact farmers within an identifiable farming group. By working with a small number of contact farmers, who were expected to pass on what they learnt to the rest of the farming group, agents were to maximize coverage. But the required staff-farmer ratios implied a significantly larger extension staff, and thus the training and visit extension systems cost some 25-40 percent more than the systems they replaced (Feder and Slade, 1993; Antholt, 1994). The design intended to deal with accountability by improving management's ability to monitor staff activities, taking advantage of the strict visit schedule, identifiable contact framers, intensive hierarchy of supervisory staff, and other quantifiable measures. The monitorable daily schedule also eliminated most activities other than information dissemination. The interaction with research was improved through seasonal meetings, but little influence was gained over research priorities (Anderson and Feder, 2004).

Several features of the $T$ and $V$ model could not stand up to practical realities, however. The quality of extension services remained mostly unmonitorable, and the lack of accountability to farmers was not resolved (Anderson and Feder, 2004). Biases in the selection of contact farmers led to diminished diffusion as contact farmers were often replaced by "contact groups". The strict biweekly visit schedule could not be maintained because agents often lacked new messages to convey and farmers had limited interest in frequent visits. The $T$ and $V$ system appeared to have little impact over time (Anderson and Feder, 2004). Although a 1986 study by Feder and Slade (1993) found a positive impact on yields in Haryana, India, three years after project initiation, studies in Pakistan (Hussain et al 1994) and Kenya (Gautam, 2000) found no significant impact after a longer period.

(b) Decentralization: Decentralization retains the public delivery and public funding characteristics of traditional centralized extension but transfers resources and responsibilities for extension to local government and communities. This approach was tried by several Latin American governments in the 1980s and 1990s (Wilson, 1991) and by Uganda (Crowder and Anderson, 2002) and other African countries later. The benefits of decentralization include: (i) gives farmers a bigger role in designing, funding, governing, executing and evaluating extension programmes; (ii) improves responsiveness and accountability of extension agents by moving services closer to the people who use them; (iii) local governments (if democratically elected) are eager to receive positive feedback on services from the clientele-electorate and this is expected to improve extension agents' incentives and induce better service; (iv) the costs of coordination with the activities of other agencies are also generally lower for local agencies operating in smaller geographical areas; and (v) political commitment may be stronger as well because the clientele is closer to the political leadership (World Bank, 2002; Anderson and Feder, 2004).

Decentralized extension services, however, are plagued by a number of problems. These include: (i) greater potential for political interference and the use of 
extension staff for other activities (such as election campaigns); (ii) economies of scale in updating staff skills can be lost, and extension-research links may be more difficult to organize; and (iii) problems of financial sustainability, rather than being resolved, may merely be transferred to the local level (Anderson and Feder, 2004). Analysis of Colombia's experience with the decentralization of extension confirms these concerns and documents a significant increase in the number of staff and thus in costs (Garfield et al, 1996).

A related reform is the devolution of extension functions to farmers' associations rather than to local governments, a strategy pursued in several West African countries with some notable successes (as in Guinea). This approach has a greater impact on accountability because the employer is closer to the clientele. There is is also greater potential for financial sustainability, because the farmers' association that provides the public good is better able to recover costs from its members (through general membership fees, for example), although government funding is generally also provided to the associations. Extension agents may be permanent employees of the associations or contract employees of private entities, non-governmental organizations, or universities. The problems with this approach include difficulties maintaining agent quality due to loss of economies of scale in training and more difficult linkages with research (Anderson and Feder, 2004).

(c) Fee-for-Service and Privatized Extension: Fee-for-service extension programmes in developing economies help reduce the fiscal burden of public extension services, though they usually entail considerable public funding even when the provider is private. Government-funded vouchers or other public support is common (Keynan et al 1997; Dinar and Keynan, 2001). Small groups of farmers typically contract for extension services to address their specific information needs. Because this solves the accountability problem, the quality of service is likely to be higher. Farmers determine the type of information that is important to them, so the impact of extension advice is likely to be high (Lindner, 1993). Defining the public good at the small group level and having the whole group share in the cost resolve, the free-rider and non-rivalry problems (Anderson and Feder, 2004). Tracing extension impact is much less of a problem than in other types of extension service provision, although issues of asymmetric knowledge of the value of information and identifiability of benefits remain and raise design challenges (Hanson and Just, 2001).

Other drawbacks of fee-for-service modes of extension include: (i) the loss of economies of scale in agent training, because agents will generally have to update their skills individually; (ii) less commercial farmers -- poorer farmers, women farmers, farmers with small or less favourable plots --- for whom the value of information is lower, may purchase fewer extension services, because the price of the service will tend to be market-determined. This may have undesirable social implications and may also be an inefficient outcome if poor farmers undervalue information because they have less ability to prejudge its value (Anderson and Feder, 2004). Also, a fully privatized extension system may result in inefficiencies 
if there are externalities, such as concerns about soil conservation (Hanson and Just, 2001).

(d) Farmer Field Schools: Farmer field schools were originally introduced to teach irrigated-rice farmers in Asia about integrated pest management (Anderson and Feder, 2004). After being implemented in Indonesia and Philippines, the programmes were replicated in other countries and for other crops, usually with significant donor funding. A typical farmer field school educates farmers on agroecosystems analysis, including practical aspects of plant health, water management, weather, weed density, disease surveillance, plus observation and collection of insect pests and beneficials (Indonesian National IPM Programme Secretariat, 1991). The approach uses participatory training methods to educate field school participants to make farmer pest observers into "confident (integrated pest management) experts, self-teaching experimenters, and effective trainers of farmers and extension workers" (Wiebers, 1993).

A programme consists of 9-12 half-day sessions of hands-on farmer, experimentation and informal training to a group of 20-25 farmers during a single crop-growing season. Initially, paid trainers lead this village-level programme, delivering diagnostics and practical solutions for overall good crop management practices (Anderson and Feder, 2004). Through group interactions, attendees sharpen their decision-making abilities and their leadership, communication, and management skills (van de Flirt, 1993). Some participating farmers are selected to receive additional training that qualifies them as farmer-trainers, with official backup support, such as training materials.

The farmer field school approach seeks to rectify the problem of accountability. The trainers who conduct the field school are bound by a street timetable of sessions and a pre-specified curriculum, which can be easily verified by supervisors. Continuous interaction with a cohesive group of trainees creates accountability to the group which is enhanced by the participatory nature of the training methods. Later, when the training is administered by farmer-trainers who are members of the community, accountability to farmers is presumed to be even greater (Anderson and Feder, 2004).

A key drawback of the farmer field school approach is its cost, which is likely to raise problems of financial sustainability. The intense training activities are expensive per farmer trained (Quizon et al, $2001 \mathrm{a}, \mathrm{b}$ ), so the amount of service actually delivered (the number of farmers trained) on a national level would be small. Cost-effectiveness and financial sustainability could be improved if farmertrainers were to become the main trainers, perhaps with significant community funding, and if informal farmer-to-farmer communications were used to facilitate knowledge diffusion (Anderson and Feder, 2004).

\section{Modifications to extension for the achievement of food security}

Some of the modifications to extension to enable it contribute to the achievement of food security include: 
(i) decentralizing resources and responsibilities for extension to local governments and communities. Decentralization can lead to services that better match local demands and needs by giving farmers a bigger role in designing, funding, governing, executing and evaluating extension programmes. Decentralization will also promote ownership, transparency and improve responsiveness and accountability of extension agents. Such decentralization will enable farmers' organizations and local governments hire experts on specific technologies, market development and other areas important to farmers.

(ii) outsourcing extension services to non-governmental organizations, private groups and others. Outsourcing will improve efficiency of delivery and accountability of extension agents, especially where a choice of providers is available (World Bank, 2002). By this arrangement, there will be a reduction in the number of extension agents employed as civil servants and use made of contracted services instead. To ensure that service providers are qualified and perform as expected, the government, will have to set and enforce standards for qualifications and performance. It will also provide training to civil servants made redundant through the reforms to ease their transition to employment in the private sector. Also, by collaborating with private initiatives and by ceding certain functions to them, public sector extension services can free more of their resources for work with poor farmers and on commodities and technologies that the private sector generally neglects (Cleaver, 1992).

(iii) sharing costs of extension services among national governments, local governments, farmers' associations, non-governmental organizations, donors and farmers. Cost-sharing makes financing of extension services more sustainable and less dependent on national budgets (World Bank, 2002). The share paid by local governments and farmers should rise as the system matures.

(iv) improving linkages among farmers, educators, researchers, extension agents, non-governmental organizations, and others. Stronger linkages improve the relevance and impact of research and extension. For example, the development of more sophisticated menus of messages will not take place unless the quality of research from which extension messages are delivered is improved. Infact, most analyses suggest that improving research capacity should now receive higher priority than strengthening extension, though both are much in need of further support. In some countries (Congo, Cote d'Ivoire, Guinea and Togo), extension and research support have been combined under a single project so as to be able to focus research more sharply on farmers' needs. Also, in Zaire where government services in the countryside have collapsed, the World Bank and government have agreed that extension should be managed by NGOs and private enterprises to which the bank provides support (Cleaver, 1992). 
(v) extension systems should work with "packages" of improved seeds, fertilizers, and cultivation practices. Where research has not yet developed improved varieties, extension workers can do surveys to discover the most sought-after local varieties and promising techniques for different conditions or that have already been proven in similar environments and help to propagate them. Much can also be learned from studying the best ten percent of farmers and deriving recommendations from their practices (Harrison, 1990). Recommendations, however, should focus on low-cost, low-risk techniques involving few or no purchased inputs (Harrison, 1990).

(vi) More work needs to be done to improve the content and quality of agricultural education and in using modern communication technology to reach farmers. In Africa, agricultural education should focus on training for low-input, labourintensive environmentally sustainable smalholder agriculture under tropical and sub-tropical conditions, rather than for high-input, mechanized farming more suited to temperate climates (Cleaver and Schreiber, 1992). This will require teachers competent in these fields as well as appropriate texts and other teaching materials. It will also require re-focusing agricultural education and widening it to include natural resource and environmental concerns.

(vii) extension should increasingly be oriented to women's needs and using women as extension agents and contact points. This is because women play a pivotal role in agriculture in developing countries. This is particularly the case in Africa where women provide most of the labour and make the key decisions for many agricultural activities. This implies not only to food production - long recognized as primarily a women's activity - but also increasingly to other agricultural activities, ranging from processing and marketing to cash cropping and animal husbandry. Yet, women have limited access to extension advice and to other forms of support such as institutional credit and improved technology for production, processing and transport (Cleaver, 1993). Bias towards male farmers is evident in the delivery of extension which is generally provided by male extension agents to men on the assumption that the extension message will "trickle across" to women. Unfortunately, it often doesn't (Saito and Weidemann, 1991). Recruiting and training more women to provide services in the public and private sectors would help in reaching women farmers. Using women's associations as contact groups has improved outreach to women in some countries, and is often more effective than working through village associations which are often led by men. In some countries, women extension volunteers selected by their communities to serve as points of contact with extension agents have proved effective in bringing advisory services to women (World Bank, 2002). Women need advice centred on simple, low-input technologies that deal with production of food crops rather than export crops and with post-harvest food storage and processing. They would also benefit from labour-saving devices to help them with transport, water pumping, and crop husbandry (Cleaver, 1993). 
(viii)while women farmers do need special extension help in view of their multiple roles in rural production and household maintenance systems and the consequent heavy demands on their time, some experts are of the view that this must be provided through an integrated extension system that helps both women and men. According to these experts, it makes no sense to have a parallel, separate system for women (Saito and Weidemann, 1991); and

(ix) systematic monitoring and evaluation of extension programmes. Careful tracking helps in focussing attention on results.

\section{SUMMARY, CONCLUSION AND RECOMMENDATIONS}

This paper reviewed: (i) the concepts of food security and food insecurity; (ii) the causes and consequences of food insecurity; (iii) the short-term and long-term measures for achieving food security; (iv) the strengths and weaknesses of different models of extension delivery; and ( $v$ ) the modifications to current extension systems for the achievement of food security. Some conclusions are that: (i) the achievement of food security in developing countries does not only rest in growth of agricultural production and reduction of population growth rates, but in the adoption of measures to address both short-run and long-run food insecurity problems; and (ii) modifications to the existing extension are imperative so that: farmers participate more actively and fully in extension; efficiency and accountability of extension is enhanced; financing of extension becomes more sustainable; the relevance and impact of extension is improved; and the special needs of rural women are addressed. The following recommendations are necessary:

(1) Given that (i) domestic farm production is a critical determinant of food security and (ii) small-scale subsistence farmers and landless agricultural labourers are most vulnerable to inadequate food intake, raising agricultural productivity, improving producers' access to inputs and increasing food availability through improved marketing systems can increase food purchasing power by raising farmer incomes and reducing consumer food prices. Falling per capita production means that people must purchase a greater percentage of their food requirements in the market place and declining per capita incomes mean that fewer people have the purchasing power to do so.

(2) Having argued for strengthening domestic food production of traditional crops, smallholder farmers also need to engage in more value-adding activities such as expanding livestock production and food processing activities using primary crops produced on the farm as raw materials. According to Borlaug and Dowswell (2004), livestock is an especially neglected area and that increased production of domestic food staples creates surpluses that can be used as livestock feed, and thus converted into milk, eggs, and meat through expanded livestock production. Considerable opportunities to add value also exist in food processing to make flours, sauces, condiments, and other processed foodstuffs for sale in local and 
distant markets. This sort of small-scale food processing can often be done with relatively simple equipment, either on the farm or by village groups.

(3) Governments should make more systematic efforts to understand who and where their food insecure are, what causes food insecurity, and what can be done to relieve it. According to the World Bank (1988), the big problems are that: (i) knowledge of these matters for individual countries is spotty; and (ii) growth strategies for developing country agriculture do not automatically target the food insecure.

(4) Governments, with some donor assistance, should prepare food security action programmes and this must be made a part of all development policies and programmes. Governments may wish to draw on the programme for the Social Dimensions of Adjustment (SDA), sponsored by the World Bank, the African Development Bank, the United Nations Development Programme, and other donors. According to the World Bank (1988), the programme will contribute to this work in three specific ways. The first is through permanent household surveys, using basic indicators to build nutritional profiles of the various population groups; the second through policy strategies on nutrition and food security; and the third through the identification, appraisal, and implementation of food security interventions for vulnerable groups in conjunction with structural and sectoral adjustment loans.

(5) Adequate attention should be paid to women and population growth -widely presumed to be the two neglected elements of food security. In Africa in particular, women are central to food security for four reasons (World Bank, 1988). The first is that most African farmers are women and increasing their productivity will determine the agricultural performance and rural incomes; second, women support children, mostly through subsistence farming and petty trade, and head many of the households at risk of food insecurity; third, women are more likely to suffer under-nutrition during pregnancy and carrying out such arduous and time-consuming tasks as fetching water; and fourth, women's nutritional status largely determines the status of their children. Specific efforts in this direction should include lifting the constraints on women's labour, conducting more research on farming systems, employment of more female extension workers to communicate directly with women's groups, increased flow of credit to women farmers and adjustments explored in land tenure that would at least assure some joint tenure for wives and husbands and more individual tenure for women.

(6) Population growth is an overriding concern for food security and for development. Governments (assisted by donors) should therefore continue to strengthen their programmes in population and family planning. This will involve promoting family planning, encouraging breastfeeding and later ages of marriage, and spreading information about the advantages of planning family size.

(7) Farmers need to be involved more actively in selecting and testing messages and in identifying the farm-level problems that should be addressed by research and extension. Often, the best way to achieve this end is by making 
farmer groups the major point of contact with extension (Cleaver, 1992). Groups are important in developing countries and need to be brought into extension programmes as partners in management. These groups should be able to guide field-level extension activities with assistance from smaller numbers of better trained extension officers.

(8) If extension services are to offer farmers the best techniques to suit their specific circumstances, they must provide "menus" of options for farmers to choose from, rather than deliver prescriptive composite technology packages. Recommendations on maize production, for example, should involve various alternatives (including simple, low-input practices as well as more complex, high-input technologies) to meet a wide range of needs. At the same time, extension should deliver recommendations for various crops and address issues that are relevant to any crop such as agroforestry, livestock-crop interactions, water control and drainage, and processing and storage (Cleaver, 1992).

(9) Increased investment in research and extension is necessary to increase agricultural productivity, thereby helping to stimulate growth, generate income, and reduce poverty. Growth in agricultural productivity can stimulate the economy by raising the incomes of producers, who then spend the resources on nontradable goods and services like housing.

(10) In the context of the New Partnership for Africa's Development (NEPAD), it is worth exploring the initiation of regional training programmes for agricultural researchers and extension workers. South Africa, through the National Agricultural Council, has developed a unique research programme that offers a limited number of young graduates an opportunity to participate in a professional development programme that is strongly linked to small- and large-scale farmers (Mkandawire, 2002). The programme equips young people with a wide range of both scientific and human-centred skills. Young researchers are attached to senior researchers, who mentor them, while they are simultaneously pursuing their studies. The mentoring processes include field experience that exposes them to the practical problems faced by smallholder or large-scale producers. Besides exposure to various research and development methodologies and their practical application in agricultural research, the young researchers are also given life skills training, including those related to working and dealing with problems of smallholder producers (Mkandawire, 2002). 


\section{REFERENCES}

Abosede, O. and J.S. McGuire. 1991. Improving Women's and Children's Nutrition in Sub-Saharan Africa: An Issues Paper, Working Paper Series, No. 723, The World Bank, Washington, D.C.

Ali, R. and B. Pitkin. 1991. "Searching for household food security in Africa". Finance and Development, 28 (4): 3-6.

Anderson, J.R. 1999. "Institutional reforms for getting an agricultural knowledge system to play its role in economic growth". Pakistan Development Review. 38(4): 33-54.

Anderson, J.R. and G. Feder. 2004. "Agricultural extension: Good intentions and hard realities". The World Bank Research Observer, 19(1): 41-60.

Anderson, J.R., J. Clement and L.V. Crowder. 1999. Pluralism and sustainable forestry and rural development: An overview of concepts approaches and future steps". In Pluralism and Sustainable Forestry and Rural Development, Food and Agriculture Organization, Rome.

Antholt, C.H. 1994. Getting Ready for the Twenty-First Century: Technical Change and Institutional Modernization in Agriculture, World Bank Technical Paper No. 217, Washington, D.C.

Barbier, E.B. 1999. The Economics of Land Degradation and Rural Poverty Linkages in Africa. UNU/INRA Annual Lectures on Natural Resource Conservation and Management in Africa. Nov. 1998, Accra, Ghana (J. J. Baidu-Forson, ed.).

Borlaug, N.E. and C. Dowswell. 2004. "Food Security and agricultural development in sub-Saharan Africa". In From Subsistence to Sustainable Agriculture in Africa, S.A. Breth (ed.), Papers from the workshop, From subsistence to Sustainable Agriculture: Policies, Strategies, and Implementation, held in Johannesburg, South Africa, Nov. 18-19.

Byerlee, D. 1998. "Knowledge intensive crop management technologies: Concepts, impacts and prospects in Asian agriculture". In Impacts of Rice Research, P. Pingali (ed.), Bangkok: Thailand Development Research Institute; Los Banos, Philippines: International Rice Research Institute.

Cernea, M.M. 1988a. Food Security and Rural Sociology, Opening Plenary Session of the VII World Congress of Rural Sociology, Bologna, Italy, June 25-31.

Cernea, M.M. 1988b. Involuntary Resettlement in Development Projects: Policy Guidelines in World Bank-Financed Projects, World Bank Technical Paper No. 80, Washington, D.C.

Cleaver, K. and G. Schreiber 1992. The Population, Agriculture and Environment, Nexus in Sub-Saharan Africa, Agriculture and Rural Development Series No. 1, Technical Department, Africa Region, World Bank, Washington, D.C. 
Cleaver, K.M. 1992a. "Deforestation in the Western and Central African Forest: The agricultural and demographic causes, and some solutions." In Conservation of West and Central African Rainforests, K. Cleaver, M. Munasinghe, M. Dyson, N. Egli, A. Peuker and F. Wencelius (eds.), The World Bank Bank, Washingto, D.C.

Cleaver, K.M. 1992b. "Making agricultural extension work in Africa". In Policy Options for Agricultural Development in Sub-Saharan Africa, N.C. Russell and C.R. Dowswell (eds.) Proceedings of a Workshop, Arlie House, Virginia, August 23-25.

Cleaver, K.M. 1993. A Strategy to Develop Agriculture in Sub-Saharan Africa and a Focus for the World Bank, World Bank Technical Paper No. 203, Washington, D.C.

Crowder, R.V. and J.R. Anderson. 2002. "Uganda: Private sector secondment of government extension agents". In Contracting for Agricultural Extension: International Case Studies and Emerging Practices, W.M. Rivera and W. Zijp. (eds.), Wallingford, United Kingdom: CABI.

Dinar, A. and G. Keynan. 2001. "Economics of paid extension: Lessons from experience in Nicaragua", American Journal of Agricultural Economics, 83(3): 769-776.

Feder G., R.E. Just and D. Zilberman. 1986. "Adoption of agricultural innovations in developing countries: A survey". Economic Development and Cultural Change, 33 (2): 255-298.

Feder, G. and R.H. Slade. 1993. "Institutional reform in India: The Case of agricultural extension". In: the Economics of Rural Organization: Theory, Practice and Policy, K. Hoff, A. Braverman and J.E. Stiglitz (eds.), New York: Oxford University Press.

Food and Agriculture Organization and World Bank. 2000. Agricultural Knowledge and Information System for Rural Development: Strategic Vision and Guiding Principles, Rome.

Garfield, E., M. Guadagni and D. Moreau. 1996. "Colombia: Decentralization of agricultural extension services", Presented to Extension Workshop, Alternative Mechanisms for Funding and Delivering Extension, The World Bank, Washington, D.C.

Garforth, C. 1982. "Reaching the rural poor: A review of extension strategies and methods". In Progress in Rural Extension and Community Development, Vol. I. G.E. Jones and M.J. Rolls (eds.), New York: Wiley.

Gautam, M. 2000. Agricultural Extension: The Kenyan Experience: An Impact Evaluation, The World Bank, Washington, D.C.

Hanson, J. and R. Just. 2001. "The potential for transition to paid extension: Some guiding economic principles", American Journal of Agricultural Economics, 83(3): 777-784. 
Harrison, P. 1990. "Sustainable growth in African Agriculture". In The Long-Term Perspective Study of Sub-Saharan Africa: Economic and Sectoral Policy Issues, The World Bank, Washington, D.C.

Hussain, S.S., D. Byerlee and P.W. Heisey. 1994. "Impacts of the Training and Visit extension system on farmers' knowledge and adoption of technology: Evidence from Pakistan," Agricultural Economics, 10(1): 39-47.

Indonesian National IPM Programme Secretariat. 1991. Farmers as Experts: The Indonesian National IPM Programme. Indonesian National IPM Programme, Jakarta.

International Food policy Research Institute (IFPRI). 1990. Annual Report, 1990. IFPRI, Washington, D.C.

Ivanic, M. and W. Martin. 2008. "Ensuring food security". Finance and Development, 45(4): 37-39.

Jain, H.K. 1988. Role of Research in Transforming Traditional Agriculture: An Emerging Perspective, ISNAR Reprint Series No. 4, The Hague, Netherlands.

Jarrett F.G. 1985. "Sources and Models of agricultural innovation in developed and developing countries", Agricultural Administration, 18(4): 217-234.

Keynan, G., M. Olin and A. Dinar. 1997. Co-financed public extension in Nicaragua", World Bank Research Observer, 12(2): 225-247.

Lele, U. 1991. Democracy and Development in Africa, International Working Paper No. 91-5, Food and Resource Economics Department, University of Florida, Gainesville, Florida.

Leonard, D.K. 1977. Reaching the Peasant Farmer: Organization, Theory and Practice in Kenya. Chicago: University of Chicago Press.

Lindner, R.K. 1993. "Privatizing the production of knowledge: Promise and pitfalls for agricultural research and extension", Australian Journal of Agricultural Economics, 37(3): 205-225.

Manyong, V.M., A. Ikpi, J.K. Olayemi, S.A. Yusuf, B.T. Omonona, V. Okoruwa and F.S. Idachaba. 2005. Agriculture in Nigeria: Identifying Opportunities for Increased Commercialization and Investment, IITA, Ibadan, Nigeria.

Mkandawire, R. 2004. "Food security strategies, and poverty eradication in Africa." In From subsistence to Sustainable Agriculture in Africa, S.A. Breth (ed.), Papers from the workshop, From Subsistence to Sustainable Agriculture: Policies, Strategies, and Implementation, held in Johannesburg, South Africa, Nov. 18-19.

Oldeman, L.R., R.T.A. Hakkeling, and W.G. Sombroek. 1990. World Map of the Status of Human-Induced Soil Degradation. Global Assessment of Soil Degradation (GLASOD). Wageningen: International Soil Reference and Information Centre and United Nations Environment Programme. 
Pingali, P., Y. Bigot and H. Binswanger. 1987. Agricultural Mechanization and Evolution of Farming Systems in Sub-Saharan Africa, Johns Hopkins University Press.

Quizon, J., G. Feder and R. Murgai. 2001b. "Fiscal sustainability of agricultural extension: The case of the farmer field school approach: Supplementary remarks". Journal of International Agricultural and Extension, 8(2): 73-76.

Quizon, J., G. Feder and R. Murgai. 2001a. "Fiscal sustainability of agricultural extension: The case of the farmer field school approach." Journal of International Agricultural and Extension Education, 8(1): 13-24.

Roberts, N. (ed.). 1989. Agricultural Extension in Africa, Proceedings of a World Bank Symposium, Eldoret, Kenya, June 20, 1984. The World Bank, Washington, D.C.

Rosen, S. and S. Shapouri. 1994. "Food security and the role of food aid". In Food Aid Needs Assessment: Situation and Outlook Series, Economic Research Service, United States Department of Agriculture, Washington, D.C.

Saito, K. and C.J. Weidemann. 1991. Agricultural Extension for Women Farmers in Africa, Discussion Paper No. 103, The World Bank, Washington, D.C.

Sanchez, P.A., A.M. Izac, I. Valencia and C. Pieri. 1996. "Soil fertility replenishment in Africa". In Achieving Greater Impact from Research Investment in Africa, S.A. Breth (ed.), Mexico City: Sasakawa Africa Association.

Sen, A. 1981. "Poverty and famines: An essay on entitlement and deprivation". Oxford: Clarendon Press.

Tomkins, A. 1981. "Nutritional status and severity of diarrhoea among pre-school children in rural Nigeria". LANCET J., 860-862.

Umali, D.L. and L. Schwartz. 1994. Public and Private Agricultural Extension: Partners or Rivals? World Bank Discussion Paper No. 236, Washington, D.C.

United States Department of Agriculture (USDA). 1992. Global Food Assessment: Situation and Outlook Report, Washington, D.C.

Van de Fliert, E. 1993. "Integrated pest management: Farmer field schools generate sustainable practices. A case study in central Java evaluating IPM training", Unpublished Ph.D. dissertation, Wageningen Agricultural University Papers 93-3. Wageningen, Netherlands.

Van den Ban, A.W. 1999. "Agricultural development: Opportunities and threats for farmers and implications for extension organizations" Journal of Agricultural Education and Extension, 6 (3): 145-156.

van den Ban, A.W. and H.S. Hawkins. 1996. Agricultural Extension, Oxford: Blackwell. 
Wiebers, Uwe-Carsten. 1993. Integrated Pest Management and Pesticide Regulation in Developing Asia. World Bank Technical Paper No. 211, Washington, D.C.

Wilson, M. 1991. "Reducing the costs of public extension services: Initiatives in Latin America". In Agricultural Extension: Worldwide Institutional Evolution and Forces for Changes, W.M. Rivera and D. J. Gustafson (eds.), Amsterdam: Elsevier.

Wodon, Q. and H. Zaman. 2008. "Rising food prices in sub-Saharan Africa: "Poverty impact and policy responses", World Bank Policy Research Working Paper No. 4738, Washington, D.C.

World Bank. 1988. The Challenge of Hunger: A Call to Action, Washington, D.C.

World Bank. 1996. Toward Environmentally Sustainable Development in SubSaharan Africa: A World Bank Agenda, Development in Practice Series. The World Bank, Washington, D.C.

World Bank. 2000a. Can Africa Claim the $21^{\text {st }}$ Century?, The World Bank, Washington, D.C.

World Bank. 2000b. World Development Indicators, The World Bank, Washington, D.C.

World Bank. 2002. From Action to Impact: The Africa Region's Rural Strategy, Washington, D.C. 